\title{
ANNOTATIONS IN THE CORPUS OF TEXTS OF STUDENTS LEARNING SLOVAK AS A FOREIGN LANGUAGE (ERRKORP)
}

\author{
MICHAELA MOŠAŤOVÁ ${ }^{1}$ - KATARÍNA GAJDOŠOVÁ \\ ${ }^{1}$ Faculty of Arts, Comenius University, Bratislava, Slovakia \\ ${ }^{2}$ L’udovít Štúr Institute of Linguistics, Slovak Academy of Sciences, \\ Bratislava, Slovakia
}

\begin{abstract}
MOŠAŤOVÁ, Michaela - GAJDOŠOVÁ, Katarína: Annotations in the corpus of texts of students learning Slovak as a foreign language (ERRKORP). Journal of Linguistics, 2019, Vol. 70, No 2, pp. $345-357$.
\end{abstract}

\begin{abstract}
The article presents the upcoming acquisition corpus of written texts of students learning Slovak as a Foreign Language and focuses on the annotation of texts, which includes information about the text as well as social and linguistic details about the student. The article also discusses the tags that identify individual errors in the texts and concept of creating the tagset itself.
\end{abstract}

Keywords: language error, learner corpus, slovak, tagging, annotation

\section{INTRODUCTION}

Language errors are immanently present in the process of learning any foreign language. The student as well as the teacher are constantly confronted with not quite successful or even unsuccessful written and spoken communication. Which is why the identification, interpretation and didactic reflection of language errors are an inherent part of teaching any foreign language - especially with the intention of reduction and prevention.

For some time, we have been aware of the need for a complex analysis of language errors in the field of Slovak as a Foreign Language (SFL) which, in 2018, led to the foundation of the collaborative project of the Studia Academica Slovaca Center at the Comenius University Faculty of Arts in Bratislava (SAS) and the Department of the Slovak National Corpus at the Ludovít Štúr Institute of Linguistics of the Slovak Academy of Sciences in Bratislava (SNC) with the aim of creating an acquisition corpus of written texts authored by foreigners learning SFL. Acquisition collections are specialized text collections with the primary use of studying processes related to the acquisition of a specific language and to its teaching. When building our corpus, we have been inspired by those of related Slavic languages, mainly Czech [1], but also the similar collections of English [2], German [3] and Russian languages [4]. 
The article presents the preparation of the first publicly accessible acquisition corpus of texts by foreigners learning SFL, entitled ERRKORP, including data collection and their metadata. The article also discusses the set of tags designed for manual annotation of collected texts. We have tested the proposed tagset on a collection of 65 texts written by students learning Slovak as a foreign language from most of the language proficiency levels (A1-C1) and a number of proveniences (Ukraine, Serbia, Italy, China, Belarus, USA, Australia). The tagset has grown more stable and precise in the course of the annotation process. We present its final version in Chapter 4. In the near future, we are planning to tag manually texts selected from the digital storage of the project and thus create a pilot version of a corpus of students learning Slovak as a foreign language. The pilot corpus version will not include a collection of testing texts.

\section{DATA COLLECTION}

There are several parallel methods and several places for the collection of data for creating the corpus. Primarily, the SAS Center is the main provider of texts for the corpus. The Center is in possession of written work by students learning SFL at the Summer School of Slovak language and culture - an event held regularly for the past 55 years, and there are also other courses taught to foreigners at the SAS center throughout the year. Texts are also shared by our visiting lecturers of Slovak Language and Culture affiliated with universities across Europe and elsewhere. The collection of texts follows the regulations of the GDPR.

Handwritten texts are being digitized and converted into text form. We understand text as a text written independently by a student who already speaks and/ or is studying SFL at a certain language proficiency level (A1-C2).

At the SNC, there is now a digital hub collecting texts written by foreigners learning SFL on the territory of Slovakia and beyond. The texts are entered online at https://errkorp.juls.savba.sk, and the provider of the texts enters information about the text as well as the Slovak speaker. At present, the corpus archive consists of 898 texts from 212 students coming from 34 countries worldwide.

\section{DOCUMENT METADATA}

For exact explication in terms of further research it is important to have access not only to the text itself but also to detailed input about the conditions in which the text was written. Also important is some information about the author of the given text, because as it is well known, a number of extra-linguistic factors contribute to the making of mistakes [5].

Metadata about the student is itemized in Table 1. A combination of entries will enable the creation of individual subcorpora with concrete specifications, these will serve for the research of a specific linguistic phenomenon or of a specific language area which has proven problematic with a given linguistic group. 


\begin{tabular}{|c|c|c|}
\hline Item description & Item & Constant values \\
\hline student's name and surname ${ }^{1}$ & spk_name & \\
\hline $\operatorname{sex}$ & spk_sex & $\begin{array}{ll}- & \text { male } \\
\text { - } & \text { female } \\
\end{array}$ \\
\hline age & spk_age & \\
\hline age group / decade & spk_decade & \\
\hline highest degree earned & spk_edu & $\begin{array}{ll}\text { - } & \text { elementary } \\
\text { - } & \text { secondary } \\
\text { - } & \text { Bachelor's degree or equivalent } \\
\text { - } & \text { Doctor's degree or equivalent } \\
\end{array}$ \\
\hline $\begin{array}{l}\text { information about the } \\
\text { student's professional } \\
\text { involvement with the } \\
\text { language }\end{array}$ & spk_jobling & $\begin{array}{ll}\text { - } & \text { yes } \\
\text { - no }\end{array}$ \\
\hline student's country of origin & spk_country1 & \\
\hline $\begin{array}{l}\text { student's current long-term } \\
\text { residence / place of study }\end{array}$ & spk_country2 & \\
\hline $\begin{array}{l}\text { mother tongue / first } \\
\text { language }\end{array}$ & spk_L1 & \\
\hline $\begin{array}{l}\text { other languages the student } \\
\text { speaks, based on proficiency } \\
\text { level e.g. ru-B2, en-B1, de- } \\
\text { A1 }\end{array}$ & spk_languages & \\
\hline $\begin{array}{l}\text { language proficiency in the } \\
\text { Slovak language }\end{array}$ & spk_level_ERR & $\begin{array}{ll} & \mathrm{A} 1.1 \\
- & \mathrm{A} 1.2 \\
\text { - } & \mathrm{A} 2.1 \\
\text { - } & \mathrm{A} 2.2 \\
\text { - } & \mathrm{B} 1 \\
\text { - } & \mathrm{B} 2 \\
\text { - } & \mathrm{C} 1 \\
\text { - } & \mathrm{C} 2 \\
\end{array}$ \\
\hline $\begin{array}{l}\text { contact with Slovak speakers } \\
\text { outside of school }\end{array}$ & spk_contact & $\begin{array}{l}\text { More than one option applicable: } \\
\text { - } \text { none } \\
\text { - parent } \\
\text { - } \text { partner, other family member } \\
\text { - friend or colleague }\end{array}$ \\
\hline
\end{tabular}

${ }^{1}$ This information is for internal purposes only. In the corpus, a student's name and surname will not be revealed. 


\begin{tabular}{|c|c|c|}
\hline Item description & Item & Constant values \\
\hline kind of stay in Slovakia & spk_stay_SR & $\begin{array}{l}\text { More than one option applicable: } \\
\text { - } \text { none } \\
\text { - } \text { study } \\
\text { - } \text { work } \\
\text { - } \text { other (visitor, family, vacation) } \\
\text { - } \text { asylum or protected status } \\
\text { - } \text { permanent residence }\end{array}$ \\
\hline length of stay in Slovakia & spk_years_SR & $\begin{array}{l}\text { - } \quad \text { less than } 6 \text { months } \\
\text { - } \quad 6-12 \text { months } \\
\text { - } 1-2 \text { years } \\
\text { - } 2 \text { years or longer }\end{array}$ \\
\hline method of studying Slovak & spk_learning & 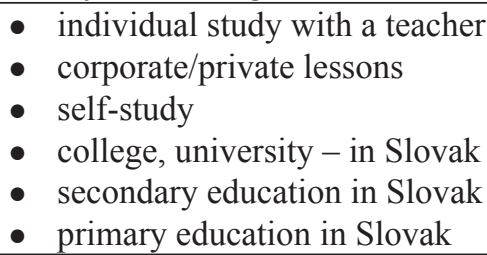 \\
\hline $\begin{array}{l}\text { other method of studying } \\
\text { Slovak }\end{array}$ & $\begin{array}{l}\text { spk_learning_ } \\
\text { other }\end{array}$ & \\
\hline \begin{tabular}{|l|} 
duration of Slovak study \\
\end{tabular} & $\begin{array}{l}\text { spk_learning_ } \\
\text { years }\end{array}$ & $\begin{array}{ll}\text { - } & \text { less than } 6 \text { months } \\
\text { - } & 6-12 \text { months } \\
\text { - } & 1-2 \text { years } \\
\text { - } & 2 \text { years or longer } \\
\end{array}$ \\
\hline $\begin{array}{l}\text { frequency of contact with } \\
\text { Slovak in hours per week }\end{array}$ & $\begin{array}{l}\text { spk_learning_ } \\
\text { hours_week }\end{array}$ & $\begin{array}{l}\text { - } \quad \text { less than } 5 \text { hours } \\
\text { - } 5-15 \text { hours } \\
\text { - } \quad \text { over } 15 \text { hours }\end{array}$ \\
\hline textbook used & spk_textbook & $\begin{array}{l}\text { - } \quad \text { selection from a list, e.g. } \\
\text { Krížom-krážom A1 }\end{array}$ \\
\hline
\end{tabular}

Tab. 1. Overview of metadata about the speaker in the upcoming ERRKORP corpus

Metadata about the text is itemized in Table 2. Their combination enables us to create suitable subcorpora with relevant values for text-oriented research, e.g. monitoring certain error types in texts written during institutional testing and their comparison with the same errors in texts from other environments, such as during self-study.

Naturally, the combination options of texts allow a great variety, especially when involving specific metadata about the student. 


\begin{tabular}{|c|c|c|}
\hline Item description & Item & Constant values \\
\hline date text was written & doc_date & YYYY-MM-DD \\
\hline $\begin{array}{l}\text { place where text was } \\
\text { written }\end{array}$ & doc_place & \\
\hline origin of text & doc_origin & $\begin{array}{l}\text { - } \quad \text { at learning institution (school, } \\
\text { course) } \\
\text { - } \quad \text { outside of learning institution }\end{array}$ \\
\hline type of text & doc_type & $\begin{array}{ll}\text { - } & \text { student's own (creative) writing/text } \\
\text { - } & \text { translation from another language } \\
\end{array}$ \\
\hline $\begin{array}{l}\text { original language in case } \\
\text { of a translation }\end{array}$ & doc_type_lang & if translation - from what language \\
\hline text form & doc_medium & $\begin{array}{l}\text { - } \text { hand-written } \\
\text { - } \text { electronic }\end{array}$ \\
\hline text as part of testing & doc_text_test & $\begin{array}{ll} & \text { yes } \\
\text { - } & \text { no } \\
\end{array}$ \\
\hline $\begin{array}{l}\text { time limit for writing the } \\
\text { text }\end{array}$ & doc_time_limit & 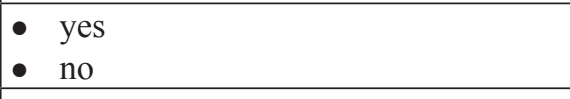 \\
\hline materials allowed & doc_materials & $\begin{array}{ll}- & \text { yes } \\
- & \text { no } \\
\end{array}$ \\
\hline type of material & $\begin{array}{l}\text { doc_material_ } \\
\text { type }\end{array}$ & $\begin{array}{ll}\text { - } & \text { dictionary } \\
\text { - } & \text { other } \\
\end{array}$ \\
\hline $\begin{array}{l}\text { material other than } \\
\text { dictionary }\end{array}$ & $\begin{array}{l}\text { doc_material_ } \\
\text { type_other }\end{array}$ & \\
\hline $\begin{array}{l}\text { text title based on } \\
\text { assignment }\end{array}$ & doc_topic & \\
\hline word count & doc_word_limit & $\begin{array}{ll} & \text { less than } 50 \text { words } \\
\text { - } & 50-150 \text { words } \\
\text { - } & \text { over } 150 \text { words } \\
\end{array}$ \\
\hline keywords & doc_keywords & \\
\hline genre of text & doc_genre & $\begin{array}{ll}\text { - } & \text { description / informational text } \\
\text { - } & \text { journalism - reporting } \\
\text { - } & \text { journalism - analyses } \\
\text { - } & \text { artistic genres / fiction } \\
\text { - } & \text { argumentation } \\
\text { - } & \text { non-fiction } \\
\text { - } & \text { administrative text } \\
\text { - } & \text { e-mail correspondence } \\
\text { - } & \text { other / unspecifiable } \\
\end{array}$ \\
\hline
\end{tabular}

Tab. 2. Overview of metadata about the text in the upcoming ERRKORP corpus 
Since with some of the texts (especially archive ones) it is not possible to identify all the items of the metadata about the text and the student, it is important to define the elementary items, which include metadata about the student - sex, country of origin, mother tongue and language proficiency level. If the given items cannot be found in archived files about a certain text, this text cannot be entered in the database.

\section{ANNOTATION SCHEME}

When creating our annotation tagset, we were inspired by the work of Stephen Pit Corder [6], Carl James [7], academic articles by Czech authors K. Šebesta and S. Škodová ([8], [9]), R. Kotková [10] and the CzeSL-SGT-cs corpus annotation tagset [11].

When annotating linguistic material, we usually apply a combination of two annotation methods.

1. First, we based our annotations on the concept of functional linguistic typology, which differentiates whether the error in the written text is:

a) on the level of a single segment - a matter of a single grapheme, diacritic, or punctuation mark and usually the error comes from the orthographic or phonetic and phonological levels of the language;

b) on the level of a word segment - thus identified errors most commonly occur in the case of a grammatical relational morpheme or derivational morpheme (prefix or suffix) or in the case of the stem, and so these are errors related to the morphological or derivational level of the language;

c) on the level of a word - these are errors on the semantic level of the language, and style. Sometimes the errors occur on the morpho-syntactic level (omitted auxiliary verbs, reflexive pronouns with reflexiva tantum),

d) on the level of a phrase within a single sentence - these are usually morphosyntactic errors: wrong congruence, wrong word order of enclitics, and lexical and stylistic errors (incorrect usage of phrases and idioms);

e) on the level of text - such errors exceed the sentence structure, these are errors of style or of pragmalinguistical character (terms unfitting a particular style of text, incorrect usage of text connectors, linking words, etc.).

2. Simultaneously, we evaluate almost every error also in terms of surface typology, according to which every error occurs as one of three options:

a) omission, or absence,

b) addition,

c) substitution (of a segment - grapheme, morpheme, word, etc.).

Annotation tags usually consist of two types of information: 1) which part of the annotated written text the error is related to (a single grapheme, diacritic, word, phrase, etc.) and 2) in what form the error occurs (omission, redundancy, or substitution). For all possible text segments that are affected by errors and which are 
also relevant for further linguo-didactic research, we chose specific tags such as comma, char for a grapheme, quant for accent (see the Tables below). In terms of surface typology, we use one of the following three tags: 0,1 or subst, e.g. if the text contains a redundant word, e.g. *budem napisat' (napišem - 'I will write down'), we use the tag word1. If a word is omitted, e.g. *opýtal ma (opýtal sa ma - 'he asked me'), we use the tag word0 and if the student used an unfitting word, which can be replaced by a different lexeme in Slovak, e.g. *idem do lekára (idem k lekárovi 'I am going to the doctor'), we annotate with the tag substword.

However, there are some possible combinations that we decided not to include in the annotation tagset due to their zero or minimal frequency in texts: for example substcomma (although the tagset includes the tags comma 0 and comma1), because this kind of error did not occur during a test of annotating.

\subsection{Errors on the level of a single segment}

Table 3 presents the tags on the level of a single segment.

\begin{tabular}{|l|l|l|}
\hline Tag & Description & $\begin{array}{l}\text { Examples (correct word/ } \\
\text { collocation - translation) }\end{array}$ \\
\hline char0 & missing grapheme & $\begin{array}{l}\text { všeci (v̌̌etci - 'all'), moe (moje - } \\
\text { 'my') }\end{array}$ \\
\hline char1 & addition of a grapheme & zamrzlina (zmrzlina - 'ice-cream') \\
\hline charmeta & exchange of subsequent graphemes & $\begin{array}{l}\text { Sbrsko (Srbsko - 'Serbia'), ked } \\
\text { (kde - 'where') }\end{array}$ \\
\hline substvow & vowel substitution & $\begin{array}{l}\text { krieslo (kreslo - 'chair'), hidiny } \\
\text { (hodiny - 'clock') }\end{array}$ \\
\hline substcons & consonant substitution & $\begin{array}{l}\text { úloga (úloha - 'task/homework'), } \\
\text { tažka (taška - 'bag') }\end{array}$ \\
\hline substdiph & diphthong substitution & $\begin{array}{l}\text { stol (stôl - 'table'), možem (môžem } \\
- \text { 'I can') }\end{array}$ \\
\hline cap0 & omission of capital letter & $\begin{array}{l}\text { minčania (Minčania, obyvatelia } \\
\text { Minska - 'inhabitants of Minsk') }\end{array}$ \\
\hline cap1 & addition of a capital letter & $\begin{array}{l}\text { Európska Únia (Európska únia - } \\
\text { 'European Union') }\end{array}$ \\
\hline alt & error in alternation & $\begin{array}{l}\text { čašníki (čašníci - 'waiters') lístoky } \\
\text { (listky - 'tickets'), mám pesa (mám } \\
\text { psa- 'I have a dog'), plakám } \\
\text { (plačem - 'I am crying') }\end{array}$ \\
\hline quantbase0 & omission of quantity in the root & $\begin{array}{l}\text { kamarat (kamarát - 'friend'), } \\
\text { kulturny (kultúrny - 'cultural') }\end{array}$ \\
\hline quantbase1 & addition of quantity in the root & $\begin{array}{l}\text { téplo (teplo - 'warm/hot'), próblem } \\
\text { (problém - 'problem') }\end{array}$ \\
\hline
\end{tabular}




\begin{tabular}{|c|c|c|}
\hline Tag & Description & $\begin{array}{l}\text { Examples (correct word/ } \\
\text { collocation - translation) }\end{array}$ \\
\hline quantpref0 & omission of quantity in the prefix & vyber (výber - 'choice') \\
\hline quantpref1 & addition of quantity in the prefix & výdanie (vydanie - 'edition') \\
\hline quantsuf0 & omission of quantity in the suffix & $\begin{array}{l}\text { novy (nový - 'new'), tuto osobu } \\
\text { (túto osobu - 'this person') }\end{array}$ \\
\hline quantsuf1 & addition of quantity in the suffix & $\begin{array}{l}\text { môžú (môžu - 'they can'), krátké } \\
\text { (krátke - 'short') }\end{array}$ \\
\hline y1 & substitution of $i-y$ & $\begin{array}{l}\text { sir (syr- 'cheese'), umit' (umyt'- } \\
\text { 'to wash') }\end{array}$ \\
\hline y0 & substitution of $\mathrm{y}-\mathrm{i}$ & $\begin{array}{l}\text { knižnyca (knižnica - 'library'), boly } \\
\text { (boli - 'they were') }\end{array}$ \\
\hline substchar & substitution of characters & $\begin{array}{l}\text { jedlo. Ktoré sa volá (jedlo, ktoré sa } \\
\text { volá- 'a dish called') }\end{array}$ \\
\hline caron0 & omission of the softness mark ( $)$ & $\begin{array}{l}\text { den (dě̌ - 'day'), cervený (červený } \\
- \text { 'red') }\end{array}$ \\
\hline caron 1 & addition of the softness mark ( () & $\begin{array}{l}\text { vo Viedňi (vo Viedni - 'in Vienna'), } \\
\text { útul'ný (útulný - 'cozy') }\end{array}$ \\
\hline comma0 & omission of a comma & $\begin{array}{l}\text { L'udia si myslia že (L'udia si myslia, } \\
\check{z} e-\text { 'People think that') }\end{array}$ \\
\hline commal & addition of a comma & $\begin{array}{l}V \text { Číne, máme dve možnosti ( } V \\
\text { Čine máme dve možnosti - 'In } \\
\text { China, we have two options') }\end{array}$ \\
\hline $\operatorname{dot} 0$ & omission of a period & $\begin{array}{l}13 \text { januára } 2016 \text { (13. januára } 2016 \\
\text { - 'January 13, 2016') }\end{array}$ \\
\hline $\operatorname{dot} 1$ & addition of a period & $\begin{array}{l}\text { v 2014. roku (v roku } 2014 \text { - 'in } \\
\text { 2014') }\end{array}$ \\
\hline hyph0 & omission of a hyphen & $\begin{array}{l}\text { krížomkrážom (križom-krážom - } \\
\text { 'criss-cross') }\end{array}$ \\
\hline hyph1 & addition of a hyphen & $\begin{array}{l}\text { rimsko-katolicky (rimskokatolicky- } \\
\text { 'Roman Catholic') }\end{array}$ \\
\hline defword & $\begin{array}{l}\text { three or more substitutions of } \\
\text { characters in a word (in the } \\
\text { root) simultaneously - with the } \\
\text { exception of incorrect diacritics }\end{array}$ & $\begin{array}{l}\text { samuslina (zmrzlina - 'ice-cream'), } \\
\text { popreč (cez - 'through') }\end{array}$ \\
\hline defdiacr & three or more errors in diacritics & $\begin{array}{l}\text { zaujimáva (zaujímavá - } \\
\text { 'interesting'), mozú (môžu - 'they } \\
\text { can') }\end{array}$ \\
\hline
\end{tabular}

Tab. 3. Annotation tags for errors on the level of a single segment 
Separately, we analyzed a set of error that are quite frequent in the Slovak language: the substitution of vowels, consonants and diphthongs. Substitution of a vowel means that a different vowel or a diphthong is used to replace the correct vowel, e. g. diesat' (desat' 'ten'). For the quantity of vowels and the syllabic " $\mathrm{r}$ " and "l" (accent) - which is linguodidactically one of the most complicated and most time consuming issues for foreigner learning SFL - we used three different tags: quantity in the prefix, quantity in the suffix (= relational morpheme) and quantity in the stem. However here, by stem we do not understand the strictly linguistic terms of stem but the part of word left after cutting off the grammatical relational morpheme and also possibly the derivational prefix, e.g. zá-hraničn-ý (zahraničný 'foreign'). This way will allow us to eventually analyze efficiently the cases where errors occur in derivational prefixes, grammatical suffixes and the stem.

The defword tag covers cases when several grapheme substitutions in a word means lack of understanding of the word, which is defective. In annotation testing, the defdiacr tag proved meaningful in cases when a word contains at least three orthographic errors but it is still comprehensible, even without diacritics (after all, present day written communication - chats, text messages, status posts on social networks, and even emails prove the usage of such texts even by native speakers).

\subsection{Errors on the level of a morpheme or word}

Table 4 introduces tags on the level of a single morpheme or word.

\begin{tabular}{|c|c|c|}
\hline Tag & Description & $\begin{array}{l}\text { Examples (correct word/collocation - } \\
\text { translation) }\end{array}$ \\
\hline word0 & omission of a word & opýtal ma (opýtal sa ma - 'he asked me') \\
\hline word1 & addition of a word & $\begin{array}{l}\text { písem s perom (píšem perom - 'I write } \\
\text { with a pen'); ja sa volám Eva (volám sa } \\
\text { Eva- 'my name is Eva') }\end{array}$ \\
\hline substword & substitution of a word & $\begin{array}{l}\text { tajná vôn̆a (tajomná vôn̆a - 'mysterious } \\
\text { fragrance'), prezentovat' parfum (darovat' } \\
\text { parfum - 'to give perfume as a gift') }\end{array}$ \\
\hline morph & $\begin{array}{l}\text { substitution of a grammatical } \\
\text { morpheme }\end{array}$ & $\begin{array}{l}\text { z galérii (z galérie (sg.) / z galérii (pl.) } \\
\text { - 'from a gallery (sg.) / from galleries' } \\
\text { (pl.)), dám svojím kamarátkam (dám } \\
\text { svojim kamarátkam - 'I will give ... to } \\
\text { my friends') }\end{array}$ \\
\hline substderiv & $\begin{array}{l}\text { substitution of a derivational } \\
\text { morpheme }\end{array}$ & $\begin{array}{l}\text { historitické (historické - 'historical'), } \\
\text { sezónové akcie (sezónne akcie - } \\
\text { 'seasonal promotions') }\end{array}$ \\
\hline gend & substitution of gender & $\begin{array}{l}\text { ten centrum (to centrum - 'the center'), } \\
\text { ten esej (tá esej - 'the essay') }\end{array}$ \\
\hline
\end{tabular}




\begin{tabular}{|l|l|l|}
\hline Tag & Description & $\begin{array}{l}\text { Examples (correct word/collocation - } \\
\text { translation) }\end{array}$ \\
\hline num & substitution of number & $\begin{array}{l}\text { koláč s ovociami (koláč s ovocím - 'fruit } \\
\text { cake'), ryža sú na tanieri (ryža je na } \\
\text { tanieri - 'rice is on the plate') }\end{array}$ \\
\hline asp & error in aspect & $\begin{array}{l}\text { budem príst' (prídem - 'I'll come') } \\
\text { zavolal, že o dva dni musel odíst' } \\
\text { (zavolal, že o dva dni musí odíst' - 'he } \\
\text { called to say that he had to leave in two } \\
\text { days') }\end{array}$ \\
\hline defmorph & $\begin{array}{l}\text { error of tense } \\
\text { morpheme }\end{array}$ & $\begin{array}{l}\text { v mojej meste (v mojom meste - 'in my } \\
\text { town'), plno ludej (plno ludí - 'a lot of } \\
\text { people') }\end{array}$ \\
\hline
\end{tabular}

Tab. 4. Annotation tags for errors on the level of a morpheme or a word

The tag substword indicates the types of mistakes where a word is substituted based on formal similarity of words or semantics. Often, these can be seen as cases of interlinguistic homonymy ("false friends"). Similar are cases on the level of the derivational morpheme, these are errors tagged as substderiv. The tag defmorph is justified when a student used a grammatical morpheme that is absent in the corresponding paradigm of the given part of speech (it is more a case of interference from the student's L1 or from another language).

\subsection{Errors on the level of word phrases within one sentence and errors on the level of text}

All tags in Table 5, especially order, congr, neg, phrase, arise from the linguodidactic need of SFL teaching to explore, on a statistically relevant sample of linguistic data, the real scope of their occurrence on the various language proficiency levels (from beginners to advanced language users) as well as in relation to language L1. The annotation of these errors shifts from verbal specification to larger sequences exceeding word sequence.

\begin{tabular}{|l|l|l|}
\hline Tag & Description & $\begin{array}{l}\text { Examples (correct word/collocation - } \\
\text { translation) }\end{array}$ \\
\hline order & word order error & $\begin{array}{l}\text { Tu nachádza sa vel'a parkov (Tu sa nachádza } \\
\text { vel'a parkov - 'There are many parks here') }\end{array}$ \\
\hline congr & congruence error & $\begin{array}{l}\text { vel'a l'udí boli (vel'a l'udí bolo - 'there were } \\
\text { many people'), pät' śtudentov majú (pät' } \\
\text { śtudentov má - 'five students have') }\end{array}$ \\
\hline
\end{tabular}




\begin{tabular}{|l|l|l|}
\hline Tag & Description & $\begin{array}{l}\text { Examples (correct word/collocation - } \\
\text { translation) }\end{array}$ \\
\hline neg & negation error & $\begin{array}{l}\text { nie budem (nebudem - 'I will not'), nikto } \\
\text { prišiel (nikto neprišiel - 'nobody came') }\end{array}$ \\
\hline space & error in splitting of words & $\begin{array}{l}\text { nie len (nielen - 'not only'), preto že (pretože } \\
\text { - 'because') }\end{array}$ \\
\hline styl & $\begin{array}{l}\text { unfitting choice of words in } \\
\text { terms of style }\end{array}$ & $\begin{array}{l}\text { na konferencii papkáme obed (na konferencii } \\
\text { jeme obed - 'we eat lunch at the conference') }\end{array}$ \\
\hline phrase & $\begin{array}{l}\text { literary translation of } \\
\text { a phrase from another } \\
\text { language }\end{array}$ & $\begin{array}{l}\text { nemá rozprávania (niet o čom - 'nothing to } \\
\text { talk about'), ich je dve (sú dve - 'there are } \\
\text { two') }\end{array}$ \\
\hline theme & $\begin{array}{l}\text { incorrect usage within the } \\
\text { text }\end{array}$ & $\begin{array}{l}\text { Ahojte, pani profesorka! (Dobrý deň, pani } \\
\text { profesorka! - 'Good morning, Miss X.') }\end{array}$ \\
\hline $\begin{array}{l}\text { structure of a sentence } \\
\text { (theme/rheme) }\end{array}$ & $\begin{array}{l}\text { Moja mama rada varí. Vel'mi dobre varí. } \\
\text { (Moja mama rada varí. Varí vel'mi dobre. } \\
\text { - 'My mom enjoys cooking. She's a great } \\
\text { cook.') }\end{array}$ \\
\hline connect & $\begin{array}{l}\text { connector error } \\
\text { (hypersyntax) }\end{array}$ & $\begin{array}{l}\text { V texte sa zaoberáme slovenčinou. } \\
\text { Jeho použivanie v rôznych situáciách } \\
\text { je ovplyvnené... (V texte sa zaoberáme } \\
\text { slovenčinou. Jej použivanie v rôznych } \\
\text { situáciách je ovplyvnené... - 'In the text, we } \\
\text { deal with the Slovak language. In various } \\
\text { situations, its usage is influenced by...') }\end{array}$ \\
\hline
\end{tabular}

Tab. 5. Annotation tags for errors on the level of a phrase within a sentence and on the level of text

\section{ANNOTATION PROCESS}

In the section about data collection we talked about converting digitized texts of students into texts. This is step zero in the process of setting up material for the acquisition corpus of texts. The following step is the manual annotation of errors based on the tagset described above. Since the project has been running on a low budget, with limited personnel capacity and high load for the annotation team, we opted for using the simplest possible annotation methods and tools. After tokenization, the annotator marks the text in a cvs file with three columns (see Table $6)$. The first column contains the student's original text vertically. In the second column, the annotator enters the corrected version of the errors from the relevant rows in the first column. The third column shows the relevant tag for the errors, based on the annotation tagset. Several errors in a single word are marked by the annotator next to each other, separated by commas. 


\begin{tabular}{|l|l|l|}
\hline$<\mathrm{s}>$ & & \\
\hline Ráno & & \\
\hline$@ @ @$ & & \\
\hline vstála & vstala & quantbase1 \\
\hline som & & \\
\hline$@ @$ @ & & \\
\hline som & & \\
\hline vstala & & \\
\hline$* @ @ @$ order & & \\
\hline, & & \\
\hline umyvala & umývala & quantbase0 \\
\hline NONE & som & word0 \\
\hline NONE & sa & word0 \\
\hline, & & \\
\hline obliekala & & \\
\hline son & som & substcons \\
\hline NONE & si & word0 \\
\hline cerveni & červené & caron0,quantsuf0,morph \\
\hline tricko & tričko & caron0 \\
\hline . & & \\
\hline$</$ s $>$ & & \\
\hline
\end{tabular}

Tab. 6. Sample of a manual text annotated

The presented tagset of errors covers the most frequently occurring errors in written texts by foreigners learning SFL. We believe that the combination of abovementioned two annotation methods creates the conditions for the most precise classification of errors with the objective of appropriate tagging of data needed for further analytical and explanatory part of research in the field of Slovak as a Foreign Language.

\section{CONCLUSION}

In the article, we introduced the concept of annotations of texts in the project of the ERRKORP acquisition corpus. In terms of the project's schedule [13], in the following months we will choose from the so far collected date in the data hub specific texts in order to include them in the pilot version of the corpus. The selected texts will be tagged manually, following the presented annotation tagset, which is also accessible free of charge as a corpus within the Slovak National Corpus. 
It will also serve for other kinds of research in the field of applied linguistics and the teaching of Slovak as a Foreign Language focusing on the study of learning SFL from various aspects (such as research of the types of errors on the respective proficiency levels, longitudinal research of errors made by individuals, or research of errors against the background of the chosen starting language, etc.).

\section{References}

[1] Šebesta, K., Bedřichová, Z., Šormová, K., Štindlová, B., Hrdlička, M., Hrdličková, T., Hana, J., Petkevič, V., Jelínek, T., Škodová, S., Poláčková, M., Janeš, P., Lundáková, K., Skoumalová, H., Sládek, Š., Pierscieniak, P., Toufarová, D., Richter, M., Straka, M., and Rosen, A. (2014). CzeSL-SGT: korpus češtiny nerodilých mluvčích s automaticky provedenou anotací, version 2 as of 28 July 2014. Ústav Českého národního korpusu FF UK, Praha. Accessible at: http: //www. korpus.cz .

[2] Granger, S., Dagneaux, E., Meunier, F., and Paquot, M. (2009). International Corpus of Learner English v2 (Handbook + CD-Rom). Louvain-la-Neuve, Presses universitaires de Louvain, Louvain-la-Neuve.

[3] Reznicek, M., Lüdeling, A., Krummes, C., Schwantuschke, F., Walter, M., Schmidt, K., Hirschmann, H., and Torsten, A. (2012). Das Falko-Handbuch. Korpusaufbau und Annotationen Version 2.01. Accessible at: https://www. linguistik. hu-berlin.de/de/institut/professuren/korpuslinguistik/forschung/falko/FalkoHandbuchV2/view.

[4] RLC. Russian Learner Corpus. Accessible at: http: / /web-corpora . net/RLC/.

[5] Pekarovičová, J. (2004). Slovenčina ako cudzí jazyk. Predmet aplikovanej lingvistiky. Bratislava, Stimul. 220 p.

[6] Corder, S. P. (1981). Error Analysis and Interlanguage. Oxford, Oxford University Press, 120 p.

[7] James, C. (1998). Errors in Language Learning and Use. London - New York, Longman, 304 p.

[8] Šebesta, K., Škodová, S. et al. (2012). Čeština - cílový jazyk a korpusy. Liberec, Technická univerzita v Liberci. 168 p. Accesible at: http://akces.ff.cuni.cz/system/fi-

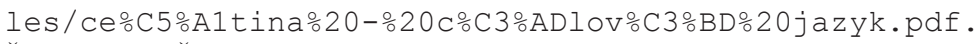

[9] Škodová, S., Štindlová, B., Rosen, A., Jelínek, T., and Vidová Hladká, B. (2019). Příručka k morfologické anotaci textů nerodilých mluvčích češtiny. Version 1.0 as of 17 January 2019. Accesible at: http://utkl.ff.cuni.cz/ rosen/public/2018_prirucka morfologicke anotace.pdf.

[10] Kotková, R. (2017). Čeština nerodilých mluvčích s mateřským jazykem neslovanským. Praha: Univerzita Karlova, $154 \mathrm{p}$.

[11] CzeSL-SGT - korpus češtiny nerodilých mluvčích s automaticky provedenou anotací. Manuál. Accessible at: http://utkl.ff.cuni.cz/ rosen/public/2014-czesl-sgt-cs.pdf.

[12] Kilgariff, A., Baisa, V., Bušta, J., Jakubíček, M., Kováŕ, V., Michelfeit, J., Rychlý, P., and Suchomel, V. (2014). The Sketch Engine: ten years on. Lexicography, 1, pages 7-36. Accessible at: http: //www. sketchengine.eu.

[13] Project of the corpus of texts written by students learning Slovak as a foreign language ERRKORP. Accessible at: https://korpus.sk/errkorp.html. 